\title{
The Role of Adult Hippocampal Neurogenesis in Learning and Memory Function
}

\author{
Erişkin Hipokampal Nörogenezin Öğrenme ve Hafıza Fonksiyonlarındaki Rolü
}

\author{
Zülal Kaptan1, Gülay Üzüm² \\ 1Biruni University İstanbul Faculty of Medicine, İstanbul, Turkey \\ 2ंstanbul University İstanbul Faculty of Medicine, Department of Physiology, İstanbul, Turkey
}

\section{Summary}

Adult hippocampal neurogenesis is the lifelong production of new functional neurons from neural stem cells in the adult brain. Production of neurons in the adult brain is limited to two areas. One of these is the subgranular region in the hippocampus dentate gyrus (DG), the other is the subventricular zone of the lateral ventricles. New neurons produced in the hippocampus DG functionally integrate into mature circuits, and contribute to cognition and emotional control, learning and memory functions in particular. It is still unclear how that contribution occurs and a key issue that is being intensively investigated. Hippocampal neurogenesis declines both with age and in neurodegenerative diseases characterized by deterioration of memory. Understanding the contribution of hippocampal neurogenesis to memory function and investigating factors that affect neurogenesis have gained importance for protective or therapeutic approaches against these neurodegenerative diseases. It is suggested that new neurons produced in the DG contribute to spatial and episodic memory function by pattern separation (prevent overlapping of similar information by making separate presentations) through their electrophysiologic properties (being stimulated easier than mature neurons) in the maturation process. Hippocampal neurogenesis is important in episodic and spatial memory formation. In this review we will try to explain how hippocampal neurogenesis occurs, factors that affect the neurogenesis process, and the role of neurogenesis in memory function based on the present literature.

Keywords: Adult hippocampal neurogenesis, dentate gyrus, learning and memory, pattern separation

\section{Öz}

Erişkin hipokampal nörogenez, erişkin beyninde yaşam boyu nöral kök hücrelerden yeni fonksiyonel nöron üretimidir. Erişkin beyninde nöron üretimi iki bölgeye sınırlıdır. Bunlardan biri hipokampus dentat girusundaki (DG) subgranüler bölge, diğeri lateral ventriküllerin subventriküler bölgesidir. Hipokampus DG'sinde üretilen yeni nöronlar fonksiyonel olarak olgun devrelere entegre olurlar, özellikle öğrenme ve hafıza fonksiyonu olmak üzere kognisyon ve emosyonel kontrole katkıda bulunurlar. Bu katkının nasıl gerçekleştiği hala açık değildir ve yoğun olarak araştırılan önemli bir konudur. Hipokampal nörogenezin hem yaşla birlikte hem yaşa bağlı hafızanın bozulması ile karakterize nörodejeneratif hastalıklarda azaldı ̆̆ı bilinmektedir. Hipokampal nörogenezin hafıza fonksiyonuna katkısını anlamak ve nörogenezi etkileyen faktörleri araştırmak bu nörodejeneratif hastalıklara karşı koruyucu ya da tedavi edici yaklaşımlar için önem kazanmıştır. Hipokampal DG'de üretilen yeni nöronların olgunlaşma süreçlerindeki elektrofizyolojik özellikleri (olgun nöronlara göre daha kolay uyarılabilir olmaları) sayesinde patern ayrımı (hipokampusa gelen benzer bilgilerin ayrı sunumları yapılarak örtüşmelerinin engellenmesi) yaparak spasyal ve epizodik hafıza fonksiyonuna katkıda bulundukları düşünülmektedir. Bu derlemede hipokampal nörogenezin nasıl oluştuğunu, nörogenez sürecine etkili faktörleri ve hafıza fonksiyonunda nörogenezin rolünü mevcut literatüre dayanarak açıklamaya çalışacă̆ız.

Anahtar Kelimeler: Erişkin hipokampal nörogenez, dentat girus, öğrenme ve hafıza, patern ayrımı

\footnotetext{
Address for Correspondence/Yazışma Adresi: Gülay Üzüm MD, İstanbul University İstanbul Faculty of Medicine, Department of Physiology, İstanbul, Turkey Phone: +90 41420 00-32601 E-mail: gulayuzum@gmail.com

Received/Gelis Tarihi: 11.01.2016 Accepted/Kabul Tarihi: 27.03 .2016

${ }^{\circ}$ Copyright 2016 by Turkish Neurological Society

Turkish Journal of Neurology published by Galenos Yayınevi.
} 


\section{Introduction}

Neurogenesis describes the development of functional neurons from neural stem cells in the brain. In the past, neurogenesis was considered to be restricted to the prenatal period, and the dogma that stated the adult brain was not capable of generating new neurons was accepted for many years. However, our current knowledge indicates that, physiologically, neurogenesis continues for a lifetime in two regions in the adult mammalian brain: the subgranular zone (SGZ) of the dentate gyrus (DG) of the hippocampus, and the subventricular zone (SVZ) of the lateral ventricles (1). Immature neurons generated by the SVZ migrate long distances to differentiate into various local interneuron groups at olfactory bulbus. In addition, new neurons generated by the neural progenitor cell population of the SGZ form neighboring excitatory granular cells of the granular layer of the DG (1). It was recently reported that neurons originating from SVZ were integrated into the olfactory bulbus in other mammals; these neurons are integrated into the striatum adjacent to the SVZ in humans (2).

The demonstration of the mitotic division capacity of neural stem cells found in certain parts of adult mammalian brain as well as differentiation of these new cells into neurons and their possible integration into existing circuits has become a major milestone of neuroscience. The importance of neurogenesis in hippocampal functioning is further emphasized with the acknowledgement of the hippocampus as a critical site for learning and memory formation, and the place where adult neurogenesis occurs.

The hippocampus is a substantial structure for episodic memory and spatial memory formation (3). Our current knowledge implies that long-term potentiation (LTP) is responsible for the cellular and molecular mechanisms that underlie learning and memory formation. LTP is defined as a permanent increase in synaptic binding power and number in response to increased neural activity frequency arriving at a presynaptic neuron or neural pathway (4). However, a large number of studies have demonstrated that LTP both strengthens the synaptic associations and fosters new neuron formation in the hippocampus during learning (4). Furthermore, newly formed neurons have been suggested to increase synaptic plasticity by being easily inducible and producing higher amplitudes (5).

The neural network changes continuously with the addition of new neurons to the hippocampal DG (6). Therefore, the hippocampus and DG have a dynamic structure. The dynamic structure of the neural network in charge of memory functions is influenced by the rate of neurogenesis, and hippocampus-related behavior. For instance, learning, exercise, and environmental enrichment both accelerate neurogenesis and improve memory (6). On the other hand, stress, aging, and several diseases with adverse impacts on memory decrease neurogenesis (6).

Although the correlation between age-related reduction in neurogenesis and impairment in cognitive functioning (7) supports the association between neurogenesis and cognitive function, this association has yet to be elucidated. Several studies have been performed recently to shed light on this issue. Does the integration of new neurons into existing hippocampal circuits influence hippocampus-related behavior? If yes, how? Why are new neurons generated? Is the inhibition of neurogenesis harmful?
Could increasing neurogenesis through pharmacologic and behavioral interventions prove beneficial? Studies in this area will lead the way to the development of preventative and treatment measures against learning and memory impairment seen in normal aging, and diseases characterized by memory impairment including Alzheimer's disease. In this review, we describe adult hippocampal neurogenesis as well as the basic factors involved in this process, and discuss the importance of neurogenesis in learning and memory formation in light of the available literature.

\section{Adult Hippocampal Neurogenesis}

Adult hippocampal neurogenesis is the life-long generation of new neurons in the DG of the hippocampus in the human brain. The term neurogenic niche describes a local microenvironment consisting of neural progenitor/stem cells with the potential to regenerate and differentiate into other cell types (glial cells and neurons). The SGZ of the hippocampal DG is one of the two neurogenic niches found in the adult brain (1). New neuron formation was first demonstrated in 1965 by Altman ve Das (8) in the DG of the hippocampus of the adult rat brain. Studies investigating the functional role of neurogenesis have gathered speed after this pioneering study. Discovery of thymine analogue 5-bromo-2'-deoxyuridin (BrdU) in the 1990s, a marker of cells with regeneration potential, followed by the definite demonstration of hippocampal neurogenesis in the adult rat brain by Heather Cameron and Elizabeth Gould, and identification of adult-born new neurons using protein markers including neural nuclear antigen (NeuN) have contributed to the evidence for neurogenesis. Adult neurogenesis was demonstrated in several species including man in the following years (9). In 1998, Eriksson et al. (10) studied postmortem brain tissue of patients injected with BrdU and neural markers, and showed neurogenesis in the DG of the adult human brain.

Adult hippocampal neurogenesis starts with the proliferation of neural progenitor cells in the SGZ (11). Very few neural progenitor cells differentiate into glia, most differentiate into granular cells in the DG (6). Physiological and morphologic maturation patterns of newborn DG cells imply that neural differentiation and short-distance migration into the granular cell layer of DG starts in the first week of life (6). These cells have not yet been synaptically integrated into the existing neural network and are activated with $\gamma$-aminobutyric acid (GABA) (12). In the second week, cells attain more neuron-like characteristics with dendrites extending into the molecular layer, and axons extending from the hilus into CA 3 to form mossy fibers. However, they are still immature neurons due to high membrane resistance and distinctive discharge characteristics. They also lack glutamatergic input due to an inadequate number of dendritic spins in the molecular layer (6). Interestingly, GABA found in the local environment causes neural depolarization in these cells via $\mathrm{Na}^{+}-\mathrm{K}^{+}-2 \mathrm{Cl}^{-}$co-carriers. At this stage, GABA is required for the maturation and survival of adult-born cells $(6,12)$. GABA-related depolarization is mediated by the cyclic adenosine monophosphate response element-binding protein. Hence, GABA is the critical neurotransmitter in neurogenesis. In this process, GABA, which is normally an inhibitory neurotransmitter, stimulates newborn neurons and prepares them for integration into existing circuits. 
Newborn DG cells establish afferent and efferent synapses with local neural networks in the third week, as well as synapses with afferent axonal fibers of the perforating pathway, originating from the entorhinal cortex (EC). Glutamatergic synaptic intake starts with the establishment of synaptic integration and the excitatory GABA input attains inhibitory characteristics (6). In the 4-6th weeks of life, DG cells are highly inducible with lower threshold values for LTP yielding higher LTP amplitudes, and exhibit stronger synaptic plasticity than mature DG cells. Newborn DG cells are indistinguishable from adult DG cells in terms of their basic physiologic and synaptic plasticity features by the eighth week (6).

Other brain chemicals are also involved in the process of new neuron generation and development. Among these, brain-derived neurotrophic factor (BDNF) is one of the most important. BDNF is involved in stimulating the differentiation of hippocampal progenitor cells into neurons and their survival (13). Furthermore, fibroblast growth factor-2 and epidermal growth factor have been shown to stimulate proliferation (14).

The functions of newborn granular cells remain unknown. However, specific electrophysiologic features of these cells in the early maturation period (prior to the $6^{\text {th }}$ week) suggest that they might be involved in learning and memory functions. Young neurons, which have low thresholds for LTP induction when events occur, have been suggested to be involved in coding, storing, and temporal association of one event with another $(15,16)$. Additionally, there is an association between adult hippocampal neurogenesis and psychiatric disorders including anxiety and depression. Permanent exposure to stress induces maladaptive fear reaction and depression, and reduces hippocampal neuron generation and survival (17). Stress-related reduction in hippocampal neurogenesis has been suggested to underlie depressive episodes. Treatments that increase serotonin levels in depression have been reported to reinforce neuron generation and survival in the DG (1). The suppressive effects of stress on neurogenesis possibly result from an increase in glucocorticoid levels (1).

\section{Factors that Affect Adult Hippocampal Neurogenesis}

Adult hippocampal neurogenesis is a multistage process that starts with the proliferation of progenitor cells and continues with their differentiation and attainment of neural phenotype. Migration of newborn neurons that survive apoptosis, and completion of their morphologic and physiological maturation is followed by their functional synaptic integration into existing circuits (1). Studies of the last two decades have shown that several factors might affect adult neural progenitor cells, including extrinsic factors such as growth factors, cytokines, chemokines, neurotrophins, steroids, and extracellular matrix molecules, and cellular intrinsic factors such as transcription factors and mediators of signalization pathways.

Adult neurogenesis is also mediated dynamically by certain behavioral factors. Manipulations regarding physical activity and environmental enrichment have increased the number of newborn granular cells and their survival rates, and improved cognitive functions in experimental animals. On the other hand, aging and stress have been shown to affect proliferation and survival phases, and eventually decrease neurogenesis and impair hippocampusrelated behavior (6).

Transplantation of progenitor cells to brain sites other than neurogenic niches have hindered neurogenesis, which emphasizes the importance of the microenvironment in this process. Neurogenic niche is localized around blood vessels, which fosters communication with the systemic environment. Animal studies have shown that certain chemokines known to increase in the plasma and cerebrospinal fluid of healthy elderly individuals decrease neurogenesis, which suggests that central and peripheral factors might modulate neurogenesis by affecting the neurogenic niche.

Microglia are distributed in the hilus and granular cell layer in the adult DG (18). Microglia constitute an important component of the neurogenic niche. During neurogenesis, microglia both remove apoptotic cells, and potentially influence proliferation, differentiation and neural survival with their secretagogues. Microglia are thought to contribute to the neurogenic niche mostly through neurotrophic factor [BDNF, insulin-like growth factor (IGF-1)], and cytokine and chemokine secretions (18). BDNF is the most important neurotrophic factor that stimulates neural stem cell proliferation and neural survival, and also a key element of memory formation. The hippocampus has very high levels of BDNF, particularly localized to the granular cells of DG. The BDNF receptor is expressed on neural stem cells. We also demonstrated in a previous study that increased neurogenesis is correlated with elevated hippocampal BDNF levels and improvement in spatial memory in calorie-restricted adolescent female rats (19). The BDNF-neurogenesis-memory association is further evidenced by the decrease in hippocampal BDNF levels and receptors with aging, and the associated impairment in neurogenesis, learning, and memory functions (20).

In addition to microglia, hippocampal astrocytes also strongly stimulate neural stem cells with their pro-neurogenic factor secretions (18). Levels of hippocampal growth factors that are known stimulators of neurogenesis including IGF-1 and vascular endothelial growth factor are significantly decreased in elderly rats compared with young rats. Altered profiles of astrocytes in aged hippocampus and reduction in their pro-neurogenic factor secretions suggest that astrocytes contribute to the protection of the neurogenic niche, and the age-related decrease in hippocampal neurogenesis is associated with reduced secretion of pro-neurogenic factors by astrocytes (18). Adenosine triphosphate, a product of astrocyte metabolism, is an important signal molecule that stimulates neural stem cell proliferation (21). The limited amount of BDNF secreted by the vascular endothelial cells physically supported by astrocytes has also been shown to contribute to neurogenesis (22).

The juxtaposition of neural progenitor cells to blood vessels suggests that important extrinsic factors involved in proliferation, neural differentiation, and survival reach these cells via the vascular route (18). Several studies reported that exercise increased neurogenesis. For instance, voluntary running has been reported to be a potential stimulator of neurogenesis by increasing cerebral blood flow (1). In recent years, calorie restriction has also been suggested to increase neurogenesis through an unknown mechanism (7). In our above-mentioned study, we also found 
that a $15 \%$ calorie-restricted diet in adolescence increased hippocampal neurogenesis, even if a normal diet was assumed in adulthood (19). Our results suggested that calorie-restricted diet increases hippocampal BDNF levels to increase neurogenesis. Also, we immunohistochemically demonstrated elevated levels of endothelial nitric oxide synthase (eNOS) in the hippocampus DG parallel with increased neurogenesis. eNOS is known to increase blood supply by causing vasodilatation of vessels. This unpublished result suggests that increased eNOS-mediated blood flow in the hippocampal neurogenic niche is the factor that stimulates proliferation.

Adult hippocampal neurogenesis might be modulated by an artificial induction of neural network efficacy. For instance, induction of LTP in DG via high frequency stimulation of the perforating pathway has increased proliferation of neural progenitor cells in the SGZ and strengthened the survival of 1-2-week-old adult-born DG cells (15). Electroconvulsive shock, which causes a brief seizure in the brain and has therapeutic effects in several emotional disorders, has also increased proliferation of neural progenitor cells and neurogenesis in the SGZ (15). Studies in patients and animal models of neurologic disorders have indicated that changes in adult hippocampal neurogenesis might be involved in the pathogenesis by triggering abnormal neural circuit activity. For example, drug-induced seizures might increase proliferation of neural progenitor cells, lead to morphologic abnormalities, ectopic migrations, and accelerated integration of adult-born granular cells (15). As a result, it is not yet clear whether changes in the rate of hippocampal neurogenesis lead to pathologic consequences (15).

\section{The Role of Adult Hippocampal Neurogenesis in Learning and Memory Functions of the Hippocampus}

The hippocampus mediates higher brain functions including learning, memory, and spatial coding (3). Declarative memory is mediated by the hippocampus and grouped into episodic and semantic memory (23). Episodic memory contains contextual information regarding when and where a particular event occurred, and what kind of an event occurred. Memories are remembered by learning, coding, consolidating new information, associating these with old information, and recalling through associations. In contrast, semantic memory contains information regarding world facts (24). Hippocampal injury both prevents learning new information and complicates remembering previous information. However, recall of older information is preserved. The latter finding implies that information is coded and consolidated in the hippocampus (transfer from short-term memory to long-term memory), and then transferred to non-hippocampal regions. The hippocampus is responsible for indexing memory traces stored in cortical areas $(25,26)$.

As previously mentioned, the hippocampus is one of the two brain areas in which adult neurogenesis occurs (1). Discovery of new neuron generation in the hippocampus, the structure responsible for learning and memory, has steered researchers into investigating the role of new neurons in hippocampal physiology and pathologies. Researchers agree that hippocampal neurogenesis contributes to learning and memory functions. However, the exact mechanism of this contribution has yet to be elucidated.
The results of computed stimulation models and experimental studies (manipulations involving transgenic animals or inhibition or stimulation of neurogenesis) indicated that the DG of the hippocampus, where adult neurogenesis occurs, is responsible for learning new information, pattern separation of similar information, distinct memory formation, and consolidation. Pattern separation is an important feature of episodic memory and is considered to be a result of adult hippocampal neurogenesis. The DG of the hippocampus prepares separate presentations of spatial and temporal associations within similar events or experiences to prevent overlapping of similar events and enables presentation as different memories (pattern separation) (15).

\section{Hippocampal Circuits}

The hippocampal regions and inter-regional connections are known to be involved in the processing of neural information. The trisynaptic circuit that contains connections between EC, DG, CA3, and CA1 forms the spine of the hippocampal network (Figure 1). The DG has a key function in the hippocampus. Cortical inputs enter the hippocampus through the DG. Stimuli from EC are transmitted to the dendrites of DG granular cells via glutamatergic excitatory synapses (the perforating pathway). The second pathway within the trisynaptic cycle is the synaptic connection between DG and CA3. Axons of DG granular cells form sparse but strong connections with the pyramidal cells of CA3 via mossy fibers. The trisynaptic pathway is completed with transmission of information from CA3 pyramidal neurons to dendrites of CA1 pyramidal neurons via Schaffer collaterals (27). Other hippocampal connections are as follows: Granular cells of the DG connect with local interneurons. These interneurons provide feedback inhibition to granular cells. The perforating pathway from the $\mathrm{EC}$ also connects with pyramidal cells of $\mathrm{CA} 3$. CA3 receives more intense but possibly weaker connections compared with

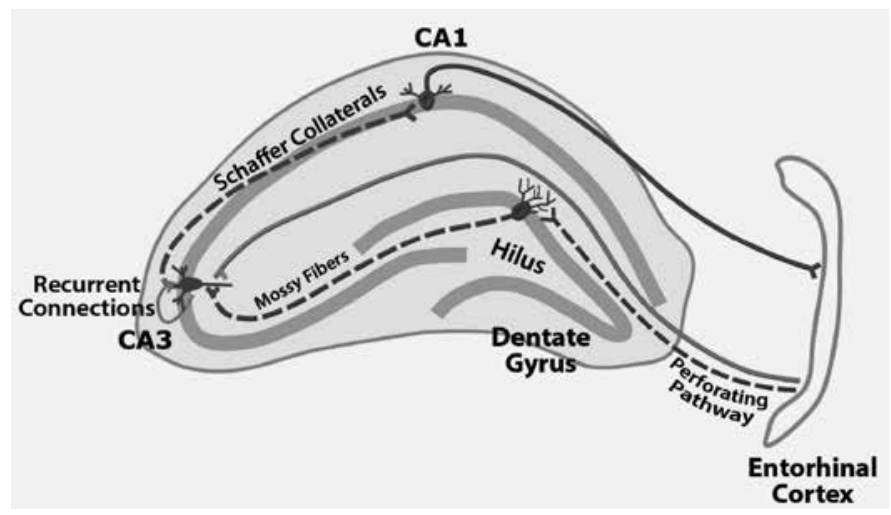

Figure 1. The trisynaptic circuit, the spine of the hippocampal circuit, contains connections between the entorhinal cortex, dentate gyrus, CA3 and CA1 (dashed lines). Part of the fibers originating from entorhinal cortex directly arrive at CA3, and other fibers arrive at the dentate gyrus (perforating pathway). Granular neurons of the dentate gyrus pass through the hilus to head towards CA3 (mossy fibers). Axons of CA3 neurons extend into CA1 (Schaffer collaterals), and axons of CA1 neurons return to the entorhinal cortex. Furthermore, there are recurrent connections within $\mathrm{CA} 3$. 
the EC. Other than the returning connections from CA3 to DG, axon collaterals of pyramidal neurons of CA3 also have recurrent connections that self-reinforce. Also, axons extend from EC to CA1. From CA1, either direct projection occurs to various cortical areas (prefrontal, anterior cingulate, orbitofrontal), or projection to these areas occurs through EC; in other words, CA1 is the exit site from the hippocampus. Hence, information arrives at the hippocampus through the EC, where it is processed, consolidated, and returned to the EC to influence all brain activity (27).

The trisynaptic circuit plays an active role in coding. Connections that enter $\mathrm{CA} 3$ and $\mathrm{CA} 1$ through the perforating pathway without arriving at the DG are predominant in recall. Evidence shows that projections from DG to CA3 via the mossy fibers are involved in the creation of new and distinctive codes but are not required for re-activation. Recurrent connections in CA3 function as an auto-association network. With these connections CA3 reinforces and stores information presented to it self, and recalls recorded patterns upon activation by the EC (28).

The rather high frequencies $(5-10 \mathrm{~Hz})$ that stimulate the perforating pathway are required to create polysynaptic activation at CA3 and CA1 through the DG and are optimum for LTP induction at the DG. Low frequencies $(0.2 \mathrm{~Hz})$ are adequate for the excitation of CA3 and CA1, but not for the activation of DG cells. Accordingly, the hippocampus exhibits oscillatory thetafrequency discharges (approximately 6-8 Hz) in an exploratory animal (29). Hippocampal theta activity is known to be associated with rapid learning (28), and neurogenesis at the DG contributes to hippocampal theta activity (30). More evidence that the DG is involved in consolidation rather than recall was shown using a Morris Water Maze; inactivation of hippocampal mossy fiber synapses impaired spatial memory formation but not recall (31).

\section{Pattern Separation}

Pattern separation defines transformation of similar inputs into separate outputs in computer modeling. Pattern separation is considered an important stage of information processing for preventing interference. A network acts as a separator if output neurons of a specific event have different discharge patterns from input neurons. This distinction can be made by changing the discharge rate or discharging neuron groups (15).

There are several reasons for holding the DG and adult-born neurons responsible for pattern separation. The number of granular cells at the DG is five times greater than that of EC cells projecting into the DG. This divergent feature allows cortical input from the EC to the hippocampus to be widely dispersed (orthogonal) at the DG. Granular cells of the DG receive positive and negative feedback inhibition via local interneurons (15). Each granular cell receives input from hundreds of EC neurons and has high baseline inhibition levels. Therefore, only neurons that specifically receive more input are activated. Neurons activated with weak stimuli are inhibited via negative feedback inhibition. This tight regulation allows each EC input (each and every one, even if similar) to activate a different DG population (sparse coding) (6). Life-long neurogenesis is the source of these different DG populations. The homeostatic mechanism has also been suggested to prevent overgrowth of available circuits with the death of existing neurons while new neurons with high plasticity are added to the circuit.
The most vigorously activated granular cells of the DG have burst discharges when experiences occur, and solely induce action potential formation at target CA3 pyramidal neurons. Spikes formed by weakly activated granular cells fail to stimulate target cells, but exert a rather stronger effect on CA3 interneuron population. This, in turn, increases the overall level of inhibition of the CA3 network (6). Such a system activates only CA3 neurons that receive input from the most vigorously activated cells, and inhibit other CA3 neurons (6). Similar inputs arriving at the hippocampus are thus sent to CA 3 after pattern separation at the DG (separate coding), and translated into associated but separate memories at $\mathrm{CA} 3$ to complete the pattern (32). Reverse projections from CA3 to immature neurons also facilitate sparse coding of DG granular cells (33). Also, the electrophysiologic features (high inducibility) of immature neurons have led to another hypothesis that suggests simultaneous events stimulate the same immature granular cell population, whereas events separated by days/weeks stimulate different granular cell masses. Hence, different granular cell populations represent events occurring at different time points and contribute to temporal separation (34).

The pattern separation function of DG has also been shown in in vivo studies. Behavioral studies of rodents with DG injury have demonstrated the role of DG in pattern separation $(35,36)$. Similarly, activity in the DG/CA3 region has been reported to correlate with pattern separation in recent fMRI studies (34). It has also been demonstrated that animals failed to differentiate similar contents in fear conditioning tests when neurogenesis was inhibited (35). On the other hand, manipulations that increase neurogenesis have resulted in better performance in location distinction and contextual fear conditioning (37). Furthermore, impairment of pattern separation has been reported in normal aging and patients with moderate cognitive impairment (35). Pharmacologic strategies aimed at stimulating hippocampal neurogenesis have been suggested to be potentially therapeutic in age-related impairment of pattern separation in the latter studies.

\section{Molecular Mechanisms Mediating Pattern Separation}

BDNF has been reported to have an important role in pattern separation in DG, although the exact molecular mechanisms of the process are unclear. Accordingly, separate storage of similar presentations requires stabilization and reinforcement of connections between CA3 and DG neurons responsible for pattern coding. Activity patterns are thought to be repeated throughout consolidation, to activate gene expression programs that reinforce the connections. BDNF has been hypothesized as the triggering factor that reinforces connections to be re-activated during recall (38).

Immature adult-born neurons are capable of responding faster to spatial input arriving at the DG due to their high plasticity. This rapid response might be susceptible to available hippocampal BDNF levels. Ablation of the BDNF receptor, tropomyosin receptor kinase B (TrkB), in progenitor cells has influenced synaptic plasticity and behavior. Accordingly, it might be possible that BDNF activates TrkB receptors in immature cells during pattern separation. BDNF expression might therefore 
be needed for coding of similar presentations in the DG. One study demonstrated that BDNF is required for the execution of a task involving pattern separation; BDNF was not an effective factor in a version of the same task without a prominent need for pattern separation. The same study also demonstrated that pattern separation was impaired with the inhibition of BDNF at DG, and injection of BDNF in the DG improved pattern separation. In addition, BDNF-dependent pattern separation occurred during coding, consolidation, and storing, but not during recall (38).

Another study implied that N-methyl-D-aspartic acid -mediated plasticity was required for rapid pattern separation in the DG (39). On the other hand, the cholinergic system has an important part in learning and memory function, as we have previously shown (40). The cholinergic system is responsible for coding information into episodic memory. Cholinergic innervation originating from the septum has been reported as the most important input regulating hippocampal theta rhythm necessary for proper hippocampal functioning (41). Additionally, deficiency of cholinergic neurons in the basal forebrain reduced the number of doublecortin (DCX) immunopositive cells in the subgranular region of the DG. DCX is expressed specifically in immature neurons (41).

\section{The Role of Adult Neurogenesis in Consolidation}

The hippocampus is needed for the consolidation of learned information during the transfer into long-term memory. Memory is stored only for a brief period in the hippocampus. Afterwards, it is transferred to other brain structures (neocortical structures including the medial prefrontal cortex, and orbitofrontal, and anterior cingulate cortex) through a process called system consolidation (42). Ongoing neurogenesis is thought to be an active process that allows deletion of old information from the hippocampus upon its transfer and storage into cortical structures, to make room for storage of new information (27).

Adult-born neurons start forming synapses at approximately 2.5 weeks and integration of these neurons into existing circuits continues for a few more weeks (43). New neurons compete with existing granular cells throughout this integration process. Compensatory changes take place to prevent over stimulation of the circuit with the addition of highly inducible immature neurons. These compensatory mechanisms include reduction of sodium flow and/or increase in potassium flow in existing DG and CA3 neurons, or reduction of inducibility via loss of receptors or endocytosis (43). The addition of new neurons weakens available hippocampal connections. As a result, old memories transferred outside of the hippocampus are cleared to make room for the storage of new information (25). Frankland et al. (43) described ongoing adult hippocampal neurogenesis as the clearing process of memories in the hippocampus. This has been termed the hippocampal "memory clearance hypothesis" (44).

Kitamura et al. (42) demonstrated that increased neurogenesis achieved with wheel spinning exercise eliminated hippocampus dependency of memory without causing any memory loss. This suggests that the match between elimination of hippocampusdependent memory and activation non-hippocampal regions (cortical regions) is important for memory recall. Adult neurogenesis is known to decrease with advancing age, in parallel with the age-related impairment in spatial memory. Considering the limited storage capacity of the hippocampus DG, hippocampal capacity for acquisition and storage of new information is expected to decrease due to reduced clearance of old memories as a result of diminished neurogenesis in aged animals.

\section{Conclusion}

The discovery of neurogenesis in the adult mammalian brain, including man, has been intriguing because it contradicts the dogma that the brain has a limited regenerative capacity. The hippocampus DG is one of the brain regions where adult neurogenesis occurs. The hippocampus is responsible for learning and memory functions. Hippocampal dysfunction has been suggested to underlie the pathogenesis of neurodegenerative diseases with age-related cognitive impairment. Therefore, it is important to investigate the role of new-born neurons in hippocampus physiology and pathology. Understanding how adult neurogenesis affects learning and memory formation, and investigating factors that affect neurogenesis are important for the development of clinical cognitive strengtheners.

\section{Ethics}

Peer-review: Externally peer-reviewed.

\section{Authorship Contributions}

Concept: Zülal Kaptan, Design: Zülal Kaptan, Data Collection or Processing: Zülal Kaptan, Gülay Üzüm, Analysis: Zülal Kaptan, Gülay Üzüm, Writing: Zülal Kaptan, Gülay Üzüm.

Conflict of Interest: No conflict of interest was declared by the authors.

Financial Disclosure: The authors declared that this study received no financial support.

\section{References}

1. Zhao C, Deng W, Gage FH. Mechanisms and functional implications of adult neurogenesis. Cell 2008;132:645-660.

2. Ernst A, Alkass K, Bernard S, Salehpour M, Perl S, Tisdale J, Possnert G, Druid H, Frisen J. Neurogenesis in the striatum of the adult human brain. Cell 2014;156:1072-1083.

3. Schmidt B, Marrone DF, Markus EJ. Disambiguating the similar: the dentate gyrus and pattern separation. Behav Brain Res 2012;226:56-65.

4. Bruel-Jungerman E, Davis S, Rampon C, Laroche S. Long-term potentiation enhances neurogenesis in the adult dentate gyrus. J Neurosci 2006;26:58885893.

5. Schmidt-Hieber C, Jonas P, Bischofberger J. Enhanced synaptic plasticity in newly generated granule cells of the adult hippocampus. Nature 2004;429:184-187.

6. Aimone JB, Deng W, Gage FH. Adult neurogenesis: integrating theories and separating functions. Trends Cogn Sci 2010;14:325-337.

7. Arslan-Ergul A, Ozdemir AT, Adams MM. Aging, neurogenesis, and caloric restriction in different model organisms. Aging Dis 2013;4:221-232.

8. Altman J, Das GD. Post-natal origin of microneurones in the rat brain. Nature 1965;207:953-956.

9. Curtis MA, Kam M, Faull RL. Neurogenesis in humans. Eur J Neurosci 2011;33:1170-1174.

10. Eriksson PS, Perfilieva E, Bjork-Eriksson T, Alborn AM, Nordborg C, Peterson DA, Gage FH. Neurogenesis in the adult human hippocampus. Nat Med 1998;4:1313-1317.

11. Zhao C, Teng EM, Summers RG, Jr., Ming GL, Gage FH. Distinct morphological stages of dentate granule neuron maturation in the adult mouse hippocampus. J Neurosci 2006;26:3-11. 
12. Pontes $A$, Zhang $Y, H u$ W. Novel functions of GABA signaling in adult neurogenesis. Front Biol (Beijing) 2013;8.

13. Waterhouse EG, An JJ, Orefice LL, Baydyuk M, Liao GY, Zheng K, Lu $\mathrm{B}, \mathrm{Xu} \mathrm{B}$. BDNF promotes differentiation and maturation of adult-born neurons through GABAergic transmission. J Neurosci 2012;32:1431814330 .

14. Mudo G, Bonomo A, Di Liberto V, Frinchi M, Fuxe K, Belluardo N. The FGF-2/FGFRs neurotrophic system promotes neurogenesis in the adult brain. J Neural Transm (Vienna) 2009;116:995-1005.

15. Deng W, Aimone JB, Gage FH. New neurons and new memories: how does adult hippocampal neurogenesis affect learning and memory? Nat Rev Neurosci 2010;11:339-350.

16. Aimone JB, Wiles J, Gage FH. Potential role for adult neurogenesis in the encoding of time in new memories. Nat Neurosci 2006;9:723-727.

17. Kaneko N, Sawamoto K. Adult neurogenesis and its alteration under pathological conditions. Neurosci Res 2009;63:155-164.

18. Aimone JB, Li Y, Lee SW, Clemenson GD, Deng W, Gage FH. Regulation and function of adult neurogenesis: from genes to cognition. Physiol Rev 2014;94:991-1026.

19. Kaptan Z, Akgun-Dar K, Kapucu A, Dedeakayogullari H, Batu S, Uzum G. Long term consequences on spatial learning-memory of low-calorie diet during adolescence in female rats; hippocampal and prefrontal cortex BDNF level, expression of NeuN and cell proliferation in dentate gyrus. Brain Res 2015;1618:194-204.

20. Katoh-Semba R, Takeuchi IK, Semba R, Kato K. Distribution of brainderived neurotrophic factor in rats and its changes with development in the brain. J Neurochem 1997;69:34-42.

21. Cao X, Li LP, Qin XH, Li SJ, Zhang M, Wang Q, Hu HH, Fang YY, Gao YB, Li XW, Sun LR, Xiong WC, Gao TM, Zhu XH. Astrocytic adenosine 5 '-triphosphate release regulates the proliferation of neural stem cells in the adult hippocampus. Stem Cells 2013;31:1633-1643.

22. Shen Q, Goderie SK, Jin L, Karanth N, Sun Y, Abramova N, Vincent P, Pumiglia K, Temple S. Endothelial cells stimulate self-renewal and expand neurogenesis of neural stem cells. Science 2004;304:1338-1340.

23. Squire LR, Zola SM. Episodic memory, semantic memory, and amnesia. Hippocampus 1998;8:205-211.

24. Schacter DL, Gilbert DT, Wegner DM. Semantic and episodic memory. Psychology. 2nd ed. New York: Worth, Incorporated, 2011:240-241.

25. Kitamura T, Inokuchi K. Role of adult neurogenesis in hippocampal-cortical memory consolidation. Mol Brain 2014;7:13.

26. Tanaka KZ, Pevzner A, Hamidi AB, Nakazawa Y, Graham J, Wiltgen BJ. Cortical representations are reinstated by the hippocampus during memory retrieval. Neuron 2014;84:347-354.

27. Wojtowicz JM. Adult neurogenesis. From circuits to models. Behav Brain Res 2012;227:490-496.
28. Bakker A, Kirwan CB, Miller M, Stark CE. Pattern separation in the human hippocampal CA3 and dentate gyrus. Science 2008;319:1640-1642.

29. Berry SD, Thompson RF. Prediction of learning rate from the hippocampal electroencephalogram. Science 1978;200:1298-1300.

30. Nokia MS, Anderson ML, Shors TJ. Chemotherapy disrupts learning, neurogenesis and theta activity in the adult brain. Eur J Neurosci 2012;36:3521-3530.

31. Becker S. A computational principle for hippocampal learning and neurogenesis. Hippocampus 2005;15:722-738.

32. Yassa MA, Stark CE. Pattern separation in the hippocampus. Trends Neurosci 2011;34:515-525.

33. Yau SY, Li A, So KF. Involvement of Adult Hippocampal Neurogenesis in Learning and Forgetting. Neural Plast 2015;2015:717958.

34. Aimone JB, Wiles J, Gage FH. Computational influence of adult neurogenesis on memory encoding. Neuron 2009;61:187-202.

35. Sahay A, Wilson DA, Hen R. Pattern separation: a common function for new neurons in hippocampus and olfactory bulb. Neuron 2011;70:582-588.

36. Gilbert PE, Kesner RP, Lee I. Dissociating hippocampal subregions: double dissociation between dentate gyrus and CA1. Hippocampus 2001;11:626-636.

37. Lange-Asschenfeldt C, Kojda G. Alzheimer's disease, cerebrovascular dysfunction and the benefits of exercise: from vessels to neurons. Exp Gerontol 2008;43:499-504.

38. Bekinschtein P, Kent BA, Oomen CA, Clemenson GD, Gage FH, Saksida LM, Bussey TJ. BDNF in the dentate gyrus is required for consolidation of "pattern-separated" memories. Cell Rep 2013;5:759-768.

39. McHugh TJ, Jones MW, Quinn JJ, Balthasar N, Coppari R, Elmquist JK, Lowell BB, Fanselow MS, Wilson MA, Tonegawa S. Dentate gyrus NMDA receptors mediate rapid pattern separation in the hippocampal network. Science 2007;317:94-99.

40. Uzum G, Diler AS, Bahcekapili N, Tasyurekli M, Ziylan YZ. Nicotine improves learning and memory in rats: morphological evidence for acetylcholine involvement. Int J Neurosci 2004;114:1163-1179.

41. Jeong DU, Lee JE, Lee SE, Chang WS, Kim SJ, Chang JW. Improvements in memory after medial septum stimulation are associated with changes in hippocampal cholinergic activity and neurogenesis. Biomed Res Int 2014;2014:568-587.

42. Kitamura T, Saitoh Y, Takashima N, Murayama A, Niibori Y, Ageta H, Sekiguchi M, Sugiyama H, Inokuchi K. Adult neurogenesis modulates the hippocampus-dependent period of associative fear memory. Cell 2009;139:814-827.

43. Frankland PW, Kohler S, Josselyn SA. Hippocampal neurogenesis and forgetting. Trends Neurosci 2013;36:497-503.

44. Oomen CA, Bekinschtein P, Kent BA, Saksida LM, Bussey TJ. Adult hippocampal neurogenesis and its role in cognition. Wiley Interdiscip Rev Cogn Sci 2014;5:573-587. 